\title{
Electrospun nanofibrous SF/P(LLA-CL) membrane: a potential substratum for endothelial keratoplasty
}

\author{
Junzhao Chen ${ }^{1, *}$ \\ Chenxi Yan ${ }^{1, *}$ \\ Mengyu Zhu',* \\ Qinke Yao' \\ Chunyi Shao' \\ Wenjuan Lu' \\ jing Wang ${ }^{2}$ \\ Xiumei $\mathrm{Mo}^{2}$ \\ Ping Gu' \\ Yao $\mathrm{Fu}^{\prime}$ \\ Xianqun Fan'
}

'Department of Ophthalmology, Ninth People's Hospital, Shanghai Jiao ${ }^{2}$ Biomaterials and Tissue Engineering Laboratory, College of Chemistry and Chemical Engineering and Biotechnology, Donghua University, Shanghai, People's Republic of China

*These authors contributed equally to this work Tong University School of Medicine,

This article was published in the following Dove Press journal:

International Journal of Nanomedicine

5 May 2015

Number of times this article has been viewed

Background: Cornea transplant technology has progressed markedly in recent decades, allowing surgeons to replace diseased corneal endothelium by a thin lamellar structure. A thin, transparent, biocompatible, tissue-engineered substratum with corneal endothelial cells for endothelial keratoplasty is currently of interest. Electrospinning a nanofibrous structure can simulate the extracellular matrix and have beneficial effects for cell culture. Silk fibroin (SF) has good biocompatibility but poor mechanical properties, while poly(L-lactic acid-co- $\varepsilon$ caprolactone) (P(LLA-CL)) has good mechanical properties but poor biocompatibility. Blending SF with P(LLA-CL) can maintain the advantages of both these materials and overcome their disadvantages. Blended electrospun nanofibrous membranes may be suitable for regeneration of the corneal endothelium. The aim of this study was to produce a tissue-engineered construct suitable for endothelial keratoplasty.

Methods: Five scaffolds containing different SF:P(LLA-CL) blended ratios (100:0, 75:25, 50:50, 25:75, 0:100) were manufactured. A human corneal endothelial (B4G12) cell line was cultured on the membranes. Light transmission, speed of cell adherence, cell viability (live-dead test), cell proliferation (Ki-67, BrdU staining), and cell monolayer formation were detected on membranes with the different blended ratios, and expression of some functional genes was also detected by real-time polymerase chain reaction.

Results: Different blended ratios of scaffolds had different light transmittance properties. The 25:75 blended ratio membrane had the best transmittance among these scaffolds. All electrospun nanofibrous membranes showed improved speed of cell adherence when compared with the control group, especially when the P(LLA-CL) ratio increased. The 25:75 blended ratio membranes also had the highest cell proliferation. B4G12 cells could form a monolayer on all scaffolds, and most functional genes were also stably expressed on all scaffolds. Only two genes showed changes in expression.

Conclusion: All blended ratios of SF:P(LLA-CL) scaffolds were evaluated and showed good biocompatibility for cell adherence and monolayer formation. Among them, the 25:75 blended ratio SF:P(LLA-CL) scaffold had the best transmittance and the highest cell proliferation. These attributes further the potential application of the SF:P(LLA-CL) scaffold for corneal endothelial transplantation.

Keywords: silk fibroin, poly(L-lactic acid-co- $\varepsilon$-caprolactone), B4G12, corneal endothelium, regeneration

Correspondence: Yao Fu; Xianqun Fan Department of Ophthalmology, Ninth People's Hospital, Shanghai Jiao Tong University School of Medicine, Number 639 Zhizaoju Road, Shanghai, 2000II,

People's Republic of China

Tel +86 $02 \mid 2327 \quad 1699$ ext 5587

Fax +86 02I 63I3 7I48

Email fuyaofy@sina.com; fanxq@shl63. net

submit your manuscript | www.dovepress.con

Dovepress

http://dx.doi.org// 0.21 477/IJN.S77706

\section{Introduction}

When the cornea is diseased, corneal tissue can be surgically removed and replaced with tissue from a deceased donor. In the last decade, several major advancements in the field of corneal endothelial transplantation have been made. Penetrating keratoplasty, which consisted of replacement of the full thickness of the cornea, was 
first performed via deep lamellar endothelial keratoplasty. ${ }^{1}$ Next was Descemet's stripping endothelial keratoplasty, with microkeratome-dissected or manually dissected donor tissue. ${ }^{2}$ In an attempt to transplant thinner grafts for better visual results, less stromal interface scarring, and less optical aberrations, Descemet's membrane endothelial keratoplasty ${ }^{3}$ and Descemet's membrane automated endothelial keratoplasty ${ }^{4}$ were then developed. At least 40,000 corneal transplants are performed in the USA each year, and of these, more than $40 \%$ now involve endothelial keratoplasty. All methods still require a donor cornea, and the worldwide shortage of transplantable donor corneas, ongoing cell damage after transplantation, and primary graft failure are issues that remain to be resolved. ${ }^{5,6}$ However, from a technical point of view, corneal surgeons are now ready to replace the diseased corneal endothelium with a thin lamellar posterior donor consisting of a tissue-engineered endothelium reconstructed on a thin carrier. ${ }^{7}$ Tissue engineered corneal endothelium may overcome the shortage.

Transplantation of isolated endothelial cells has been performed in animals. ${ }^{8}$ Methods for the isolation and in vitro cultivation of human corneal endothelial cells (HCEC) have been established, ${ }^{9}$ and transplantation of cells expanded in vitro may become an alternative option to using cells directly from a donor. ${ }^{10}$ This would reduce the demand for donor tissue and allow a ready supply of material with consistently high numbers of viable cells; it would also minimize the risk of microbial or prion transfer from the donor. The next task is to find a suitable carrier.

Tissue-engineered endothelium should be highly functional (a transparent substratum with an organized monolayer of cells) and should be delivered on a biocompatible carrier in a format compatible with the surgical techniques currently available for transplantation (ie, allow precise surgical insertion and fixation). ${ }^{11}$ Additionally, the tissue-engineered endothelial transplant needs to be long-lasting. Many materials have been used as substrata for corneal endothelial cell growth. ${ }^{7}$ These include amniotic membranes, the basement membrane of amniotic membranes, gelatin membranes, anterior crystalline lens capsule, living native stroma, devitalized native stroma, and more recently, silk fibroin (SF) membranes. ${ }^{7,12-14}$ Among these, the SF membrane seems to be one of the most promising membrane materials. Bray et al and Harkin et al reported the use of an SF membrane in corneal tissue engineering. ${ }^{15,16}$ The fibroin membrane exhibited many advantages in their reports, but without a coating, it did not support good attachment and growth of the HCEC line (B4G12) or primary endothelial cells.
Recently, researchers have found that nanofibrous structures formed by electrospinning could promote cell attachment, spreading, proliferation, and migration. ${ }^{17,18}$ However, an electrospun SF membrane has weak mechanical properties. ${ }^{19}$ Poly(L-lactic acid-co- $\varepsilon$-caprolactone) $[\mathrm{P}(\mathrm{LLA}-\mathrm{CL})]$ is a copolymer of L-lactic acid and $\varepsilon$-caprolactone. ${ }^{20}$ The potential use of electrospun P(LLA-CL) scaffolds in tissue engineering has been investigated as a result of the controllable degradation rate and mechanical properties achieved using different molar ratios of L-lactic acid/ $\varepsilon$-caprolactone. ${ }^{21}$ P(LLA-CL) scaffolds have been reported to enhance retinal pigment epithelial culture. ${ }^{22}$ For synthetic materials, the main disadvantage is the lack of natural cell recognition sites. ${ }^{23}$ Electrospinning SF/P(LLA-CL) blends may generate a new scaffold to overcome the disadvantages mentioned above.

The objective of our present study was to fabricate different blending weight ratios of nanofibrous SF/P(LLA-CL) scaffolds and to assess the potential value of nanofibrous SF/P(LLA-CL) scaffolds in corneal endothelial engineering. The cytocompatibility, monolayer formation, and effect of interaction between nanofibrous scaffolds and B4G12 cells were studied.

\section{Materials and methods Electrospinning materials}

Bombyx mori silkworm cocoons were kindly supplied by Jiaxing Silk Co Ltd (Jiaxing, People's Republic of China). A P(LLA-CL) polymer (molecular weight 300,000, LA to CL mole ratio 50:50) was provided by Nara Medical University (Kashihara, Japan). 1,1,1,3,3,3,-Hexafluoro-2-propanol was purchased from Daikin Industries Ltd (Osaka, Japan).

\section{Preparation of regenerated SF}

Raw silk was degummed using a 0.5 wt $\%(0.02 \mathrm{M}) \mathrm{Na}_{2} \mathrm{CO}_{3}$ (Sigma-Aldrich, St Louis, MO, USA) solution at $100^{\circ} \mathrm{C}$ three times for 30 minutes each to remove the sericin gum and then washing with distilled water. The degummed silk was dissolved in a ternary solvent system of $\mathrm{CaCl}_{2} / \mathrm{H}_{2} \mathrm{O} /$ ethanol (mole ratio $1 / 8 / 2$ ) for 1 hour at $70^{\circ} \mathrm{C}$. After dialysis through a cellulose tubular membrane (250-257 $\mu \mathrm{m}$, Sigma-Aldrich) in distilled water for 3 days at room temperature, the SF solution was filtered and lyophilized to obtain regenerated SF sponges.

\section{Electrospinning}

P(LLA-CL) and SF were dissolved in hexafluoroisopropanol and blended with different weight ratios of SF to P(LLA-CL) $(100: 0,75: 25,50: 50,25: 75,0: 100)$ to a final 
concentration of $8 \% \mathrm{w} / \mathrm{v}$. Six solutions were then stirred at room temperature for 6 hours. To create nanofibrous scaffolds, the blended solutions were placed into a $2.5 \mathrm{~mL}$ plastic syringe with a blunt-ended needle. The syringe was housed in a syringe pump $(789100 \mathrm{C}$, Cole-Parmer Instrument Company, Vernon Hills, IL, USA) and dispensed at a rate of $1 \mathrm{~mL}$ per hour. Using a high-voltage power supply (BGG6-358) a voltage of $12 \mathrm{kV}$ was applied across the needle and ground collector. A flat grounded steel plate covered with aluminum foil placed $11 \mathrm{~cm}$ from the needle and a steel rotating disc with a rotation speed of 1,500 rpm were used for collecting the aligned nanofibers onto $15 \mathrm{~mm}$ glass coverslips upon the plate. After electrospinning, all of the fibrous meshes were dried under vacuum (50 mbar, $25^{\circ} \mathrm{C}$ ) for 72 hours.

\section{Characterization of SF/P(LLA-CL) nanofibers}

\section{Diameter}

The morphology of the nanofibers was observed using a JSM6701 scanning electron microscope (SEM; JEOL, Tokyo, Japan). The mean fiber diameter was estimated using ImagePro Plus 6.0 software and calculated by selecting 100 fibers randomly observed on the SEM images.

\section{Mechanical measurements}

The mechanical properties of the nanofibers were determined by applying tensile test loads to specimens prepared from the electrospun scaffolds with different blend ratios of SF to P(LLA-CL) (100:0, 75:25, 50:50, 25:75, 0:100). The specimens had a planar dimension of width $\times$ gauge length $=15 \mathrm{~mm} \times 30 \mathrm{~mm}$. Their mechanical properties were tested using a H5K-S materials testing machine (Hounsfield Test Equipment Ltd, Redhill, UK) at a temperature of $20^{\circ} \mathrm{C}$, a relative humidity of $65 \%$, and an elongation speed of $10 \mathrm{~mm}$ per minute. Each sample was measured six times. Specimen thicknesses were measured using a digital micrometer, which has a precision of $1 \mu \mathrm{m}$.

\section{Contact angle measurements}

Surface wettabilities of the electrospun scaffolds were characterized by measurement of the water contact angle. Distilled water was automatically dropped onto the electrospun scaffolds. The images of the droplets on the membrane after 8 seconds were visualized using an OCA40 image analyzer (Dataphysics, San Jose, CA, USA), and the angles between the water droplet and the surface were measured. Angle changes over time were measured automatically. The contact angle was measured three times from different positions, and an average value was calculated.

\section{Measurement of light transmission}

Light transmission through the fibroin membrane was measured with a Synergy microplate spectrophotometer (Bio-Tek Winooski, VT, USA). Fifteen millimeter glass coverslips with scaffolds were placed in a 24-well culture plate. Next, $1 \mathrm{~mL}$ of $0.01 \mathrm{M}$ phosphate-buffered saline (PBS, SigmaAldrich) was added. The measurements were repeated with triplicate samples, and the background was determined using glass coverslips alone in PBS.

\section{HCEC-B4G I 2 cells cultured on nanofibrous scaffolds \\ Cell culture}

An immortalized human corneal endothelial (B4G12) cell line, as an ideal model of differentiated HCEC, was used to test biocompatibility. ${ }^{24}$ This clonal cell line was purchased from the Creative Bioarray Company (Shirley, NY, USA). HCEC-B4G12 cells were cultured in Dulbecco's Modified Eagle's Medium containing 10\% fetal bovine serum and $100 \mathrm{U} / \mathrm{mL}$ penicillin-streptomycin (all from Gibco, Carlsbad, CA, USA). The cultures were incubated in a humidified atmosphere of $5 \% \mathrm{CO}_{2}$ at $37^{\circ} \mathrm{C}$. The medium was replaced every other day.

\section{Cell seeding}

The nanofibrous scaffolds obtained were placed in a desiccator saturated with $75 \%$ ethanol vapor at $25^{\circ} \mathrm{C}$ for at least 24 hours, making them sterile. Each of the nanofibrous scaffolds was sterilized under an ultraviolet lamp for 30 minutes at room temperature in a 24 -well culture plate. The specimens were rinsed three times with sterilized PBS and immersed in culture medium for 10 minutes at $37^{\circ} \mathrm{C}$ prior to cell seeding. The cultured HCEC-B4G12 cells were dissociated into single-cell suspensions and seeded at a density of $0.5 \times 10^{5} /$ well onto polymer scaffolds with a total volume of $1 \mathrm{~mL}$ of culture medium in 24-well plates.

\section{Cell adherence}

HCEC-B4G12 cells were cultured in a 24-well culture plate for 4 hours; the medium was then replaced with PBS, and the cells were washed three times to remove nonadhered cells. The cell numbers on both the electrospun scaffolds and tissue culture plate surface, which was used as a control, were determined using the 3-(4,5-dimethylthiazol-2-yl)-2,5diphenyltetrazolium bromide (MTT) method. Briefly, the 
cells were incubated with $5 \mathrm{mg} / \mathrm{mL}$ MTT for 4 hours. The culture medium was then extracted and $1 \mathrm{~mL}$ of dimethyl sulfoxide was added for approximately 20 minutes. When the crystal was sufficiently resolved, aliquots were pipetted into the wells of a 96-well plate and tested using an ELx800 microplate spectrophotometer (Bio-Tek); the absorbance at $490 \mathrm{~nm}$ was measured for each well. To determine the background absorbance, electrospun scaffolds without cells were evaluated using the same steps described above.

\section{Cell immunocytochemistry}

\section{Live-dead viability assay}

Viability staining was performed using a calcein acetoxymethyl ester/ethidium homodimer 1 assay (Invitrogen, Carlsbad, CA, USA) as previously described by Eidet et al. ${ }^{25}$ In brief, HCEC-B4G12 cells were cultured for 3 days in culture medium on nanofibrous scaffolds or glass coverslips (control group). The cells were then incubated in PBS containing $2 \mathrm{mM}$ calcein acetoxymethyl ester and $2 \mathrm{mM}$ ethidium homodimer 1 (at $37^{\circ} \mathrm{C}$ for 45 minutes) and washed with PBS. All glass covers were mounted on cover slip glass slides.

\section{Immunocytochemistry of $\mathrm{Ki}-67$ protein}

After 3 days of culture, the HCEC-B4G12 cells were fixed with 4\% paraformaldehyde (Sigma-Aldrich) dissolved in PBS, permeabilized with $0.3 \%$ Triton X-100 (SigmaAldrich) in PBS, and blocked with 10\% normal goat serum (Invitrogen). The cells were then subjected to mouse monoclonal anti-Ki-67 (1:200, BD Biosciences, Franklin Lakes, NJ, USA) at $4^{\circ} \mathrm{C}$ for 16 hours. The coverslips were washed three times for 10 minutes each in PBS. Fluorescently labeled secondary antibodies (Alexa Fluor 488 goat antimouse immunoglobulin G, BD Biosciences) were applied at a dilution of 1:500 in PBS for 1 hour. After washing three times with PBS, the cell nuclei were counterstained with 4,6-diamidino-2-phenylindole (DAPI, Invitrogen). The negative control samples were processed in parallel without any primary antibody.

\section{Immunocytochemistry staining for incorporation of BrdU}

The cells were cultured for 4 hours in the presence of $10 \mu \mathrm{M}$ BrdU (Sigma-Aldrich), fixed in 4\% paraformaldehyde for 15 minutes at room temperature, and incubated with blocking buffer (PBS containing 10\% normal goat serum, $0.3 \%$ Triton X-100, and $100 \mathrm{ng} / \mathrm{mL}$ RNase A) for 60 minutes at room temperature. The cells were then washed in PBS, incubated with $1 \mathrm{~N} \mathrm{HCl}$ for 30 minutes at room temperature, and washed in Hanks' Balanced Salt Solution followed by PBS at room temperature. After overnight incubation at $4^{\circ} \mathrm{C}$ with anti-BrdU antibody (1:200, Santa Cruz Biotechnology, Santa Cruz, CA, USA) in blocking buffer, the cells were washed in PBS and incubated with fluorescent-conjugated secondary antibody (Alexa Fluor 488-goat anti-mouse, 1:500) for 1 hour at room temperature. The cell nuclei were counterstained with DAPI.

Fluorescent images of the nanofibrous scaffolds were recorded using an Axiovert 100 LSM710 laser scanning confocal microscope (Carl Zeiss, Oberkochen, Germany). The number of live and dead cells (showing green and red fluorescence, respectively) and amounts of BrdU and Ki-67 protein staining were counted in five fields at a magnification of $200 \times$, and the percentages of live cells and positive cells were calculated.

\section{Formation of a monolayer on electrospun scaffolds}

HCEC-B4G12 cells were cultured on the scaffolds for 7 days to form a monolayer with well-formed cell tight junctions. The monolayers were imaged using SEM and zonula occludens (ZO)-1 immunocytochemistry staining. Briefly, for SEM observation, the cell-cultured scaffolds was fixed in $4 \%$ glutaraldehyde for 2 hours at $4^{\circ} \mathrm{C}$. Following three rinses with distilled water, the samples were dehydrated through a graded ethanol series and then freeze-dried. Dry constructs were sputter-coated with platinum and observed by SEM. For immunocytochemistry staining, the scaffolds was blocked with $10 \%$ normal goat serum for 60 minutes at room temperature after being fixed in 4\% paraformaldehyde for 15 minutes. The cells were then subjected to rabbit polyclonal anti-ZO-1 (1:50, Invitrogen) at $4^{\circ} \mathrm{C}$ for 16 hours. The coverslips were washed three times for 10 minutes each in PBS. Fluorescently labeled secondary antibodies (Alexa Fluor 488 goat anti-rabbit immunoglobulin G, BD Biosciences) were applied at a dilution of 1:300 in PBS for 1 hour. After washing three times with PBS, the cell nuclei were counterstained with DAPI. Fluorescent images were recorded by confocal microscopy.

\section{Detection of gene expression} Isolation of RNA

Scaffolds with cells were removed from the coverslips using microscope forceps and were immersed in RNA extraction buffer. ${ }^{26}$ The scaffolds were ground on ice using a Bio-Gen Pro200 homogenizer (PRO Scientific Inc, Oxford, CT, USA). Total RNA was extracted from each sample using an RNeasy mini kit (Qiagen, Valencia, CA, USA). RNA samples were treated 
with DNase I (Qiagen) to digest and eliminate any contaminating genomic DNA. The RNA concentration was measured at a wavelength of $260 \mathrm{~nm}$ (A260), and the purity of total RNA was determined by the A260/A280 ratio. Quantitative polymerase chain reaction (qPCR) analyses were only performed on samples with A260/A280 ratios between 1.9 and 2.1.

\section{Reverse transcription and $\mathrm{qPCR}$}

Two micrograms of total RNA in a $20 \mu \mathrm{L}$ reaction volume were reverse-transcribed using the PrimeScript ${ }^{\mathrm{TM}} \mathrm{RT}$ reagent kit (Perfect Real Time; TaKaRa, Dalian, People's Republic of China). qPCR was carried out in a $20 \mu \mathrm{L}$ solution containing $10 \mu \mathrm{L}$ of reaction mixture, $1 \mu \mathrm{L}$ of complementary DNA, $2 \mu \mathrm{L}$ of primers (Table 1 for primer sequences), and $7 \mu \mathrm{L}$ of doubled-distilled $\mathrm{H}_{2} \mathrm{O}$. The qPCR was conducted using a 7,500 real-time PCR detection system (Applied Biosystems, Irvine, $\mathrm{CA}, \mathrm{USA})$ and was activated at $95^{\circ} \mathrm{C}$ for 10 minutes and 40 cycles of amplification $\left(15\right.$ seconds at $95^{\circ} \mathrm{C}$ and 1 minute at $60^{\circ} \mathrm{C}$ ). The PCR efficiency of the reaction was measured with primers by using serial dilutions of the complementary DNA $(1: 1,1: 5,1: 25,1: 125,1: 625$, and 1:3,125). Each sample was tested in triplicate. Relative gene expression was analyzed using the Pfaffl method. ${ }^{13}$ The data are expressed as the fold change relative to B4G12 cultured on a normal 24-well plate after normalizing to glyceraldehyde3-phosphate dehydrogenase.

\section{Statistical analysis}

All data presented in this study are shown as the mean \pm standard deviation unless specifically indicated otherwise. Each experiment was repeated at least three times. Statistical analyses were performed on the data obtained using one-way analysis of variance. $P \leq 0.05$ was taken to indicate a statistically significant difference.

\section{Results}

\section{Characterization of nanofibrous membranes with different blend ratios}

The basic features of nanomembranes with the five different blend ratios are shown in Table 2. The pure SF electrospun scaffold had the thinnest nanofiber diameter, the lowest tensile strength, and the smallest thickness. This scaffold was also very hydrophilic. As the concentration of P(LLA-CL) increased, the diameter, thickness, tensile strength, and water contact angle also gradually increased. All the nanofibrous membranes were electrospun on glass coverslips, so cover glass was used as the control. Glass coverslips with and without membranes were placed into a 24 -well plate, and each

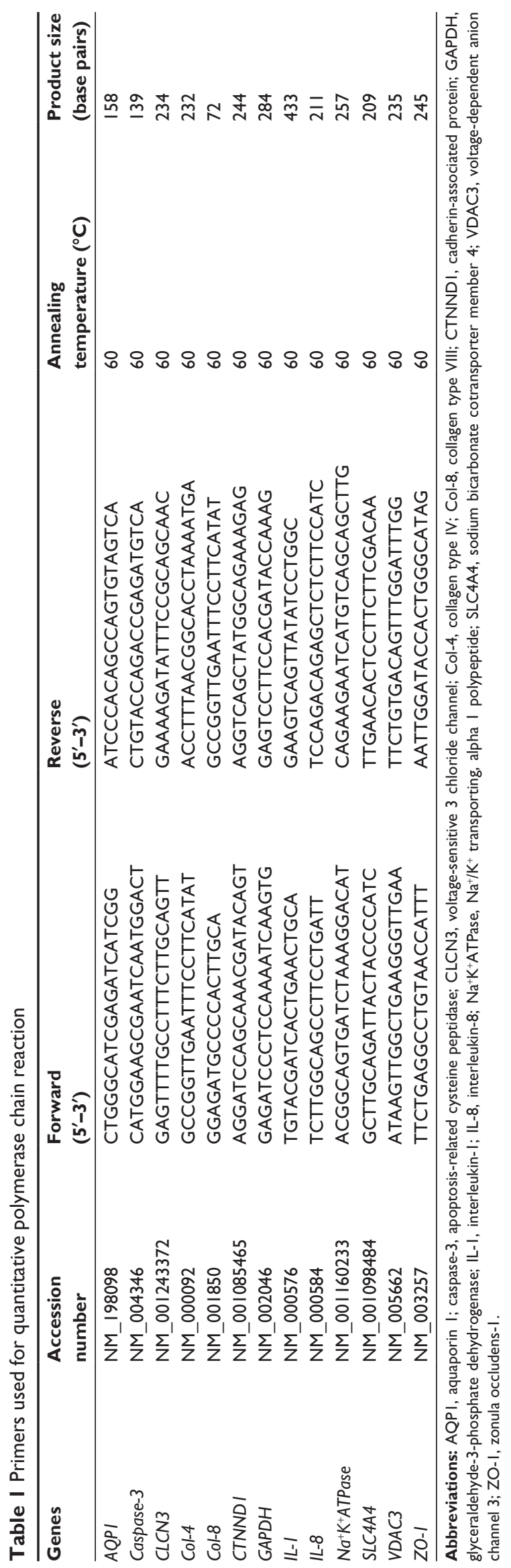


Table 2 Basic features of the blended nanofibrous membrane

\begin{tabular}{lllll}
\hline $\begin{array}{l}\text { SF:P(LLA_CA) } \\
(8 \% \text { w/v) }\end{array}$ & $\begin{array}{l}\text { Nanofiber diameter } \\
(\mathbf{n m})\end{array}$ & $\begin{array}{l}\text { Specimen thickness } \\
(\mu \mathbf{m})\end{array}$ & $\begin{array}{l}\text { Contact angle at } \\
\mathbf{2 0} \text { seconds (degrees) }\end{array}$ & $\begin{array}{l}\text { Tensile strength } \\
(\mathbf{M P a})\end{array}$ \\
\hline $100: 0$ & $147 \pm 24$ & $30 \pm 9.53$ & $38.36 \pm 0.41$ & $1.90 \pm 0.75$ \\
$75: 25$ & $226 \pm 31$ & $56 \pm 5.12$ & $49.03 \pm 0.67$ & $2.39 \pm 0.22$ \\
$50: 50$ & $255 \pm 37$ & $62.5 \pm 7.93$ & $62.93 \pm 0.50$ & $5.29 \pm 0.66$ \\
$25: 75$ & $226 \pm 24$ & $56 \pm 4.20$ & $71.58 \pm 0.15$ & $9.39 \pm 0.69$ \\
$0: 100$ & $542 \pm 107$ & $128 \pm 6.65$ & $125.78 \pm 0.02$ & $7.47 \pm 0.38$ \\
\hline
\end{tabular}

Note: Data are shown as the mean \pm standard deviation, unless otherwise specified. Abbreviations: SF, silk fibroin; P(LLA-CL), poly(L-lactic acid-co- $\varepsilon$-caprolactone).

well was filled with $1 \mathrm{~mL}$ of PBS to wet the membrane. The transmission of the different nanofibrous blend ratios is shown in Figure 1A. The surfaces of five blend ratio scaffolds were observed by SEM and are shown in Figures 1B-1F. More accurate results detected by spectrophotometry are shown in the line chart in Figure 1G. When the SF:P(LLA-CL) blend ratio was $25: 75$, transmission was highest at approximately $90 \%$ of glass coverslips (approximately $90.57 \%$ at $700 \mathrm{~nm}$ ). Pure SF and P(LLA-CL) electrospun scaffolds were less transparent than the combined materials.

\section{Adherence of HCEC-B4G 12 cells to nanoscaffolds with different blend ratios}

The violet crystals formed in the MTT test can semiquantitatively reflect the number of living cells present in cell proliferation studies. Here, we utilized the MTT test to measure the number of cells adhered to the different nanoscaffolds, using a normal tissue culture plate dish surface as the control. Figure 2A shows the number of B4G12 cells implanted on the nanoscaffolds after 4 hours. Numerous violet crystals were observed on the 25:75 SF:P(LLA-CL) blend ratio membrane and the pure $\mathrm{P}(\mathrm{LLA}-\mathrm{CL})$ membrane, turning these membranes dark purple in color. Figure 2B shows the absorbance at $490 \mathrm{~nm}$ after dissolving in dimethyl sulfoxide. A histogram showed that the absorbance for all the electrospun scaffolds was higher than that of the tissue culture plate surface. Absorbance tended to increase with increasing blend ratios of $\mathrm{P}(\mathrm{LLA}-\mathrm{CL})$. The SF:P(LLA-CL) blend ratio of 25:75 showed the highest absorbance ( $0.65 \pm 0.032)$, but this was not significantly different from that of the pure P(LLA-CL) scaffold (0.62 \pm 0.035$)$.

\section{Cell viability and proliferation on different SF/P(LLA-CL) membranes}

A live-dead kit was used to evaluate the toxicity of the materials. No significant differences were found between any of the groups using the live-dead kit, as shown in Figure 3A. Figure $3 \mathrm{~A}$ also shows the immunocytochemistry staining for Ki-67 protein and BrdU. These two indicators reflect cell proliferation and the similar cell proliferation tendency were observed. Figure 3B shows that two SF:P(LLA-CL) blend ratios, ie, 25:75 and 50:50, had the same proliferation ability as the control group on Ki-67 protein staining, while Figure 3C shows that the 25:75 SF:P(LLA-CL) blend ratio had the same proliferation ability as the control group on BrdU staining.

\section{Formation of a monolayer on different SF/P(LLA-CL) membranes}

SEM results are shown in Figure 4A. A cell monolayer formed on the different scaffolds and on the control surface after 7 days of culture. Full functioning of the cell barrier requires tight junctions between corneal endothelial cells, so ZO-1 immunocytochemistry staining was performed. As seen in Figure 4B, ZO-1 was marked by green fluorescence and it indicated that corneal endothelial cells formed a good shape on the scaffolds around the cell in monolayers in all six groups. These results demonstrated not only the formation of a monolayer of B4G12 cells on the scaffolds but also the formation of tight junctions between cells.

\section{Gene expression}

Messenger RNA levels for seven functional genes that were detected by real-time PCR are shown in Figure 5A. Most were stably expressed on the different scaffolds, and at the same levels as on the control surface. Only two genes appeared to change by more than \pm 2 -fold on some scaffolds. Aquaporin- 1 mRNA showed a 2.73-fold and 2.65-fold increase, respectively, on the scaffolds with SF:P(LLA-CL) blend ratios of 50:50 and 25:75. Messenger RNA levels for sodium bicarbonate cotransporter 4 (SLC4A4) showed changes on the scaffolds containing P(LLA-CL) [2.08-fold on $25 \%$ P(LLA-CL), 2.04-fold on 50\% P(LLA-CL), 2.612-fold on $75 \%$ P(LLA-CL), and 3.66-fold on $100 \%$ P(LLA-CL)]. The SLC4A4 mRNA level only changed by 1.64 -fold on the pure SF nanomembrane. Two extracellular matrices, collagen IV and VIII, were detected by real-time PCR. Figure 5B shows 

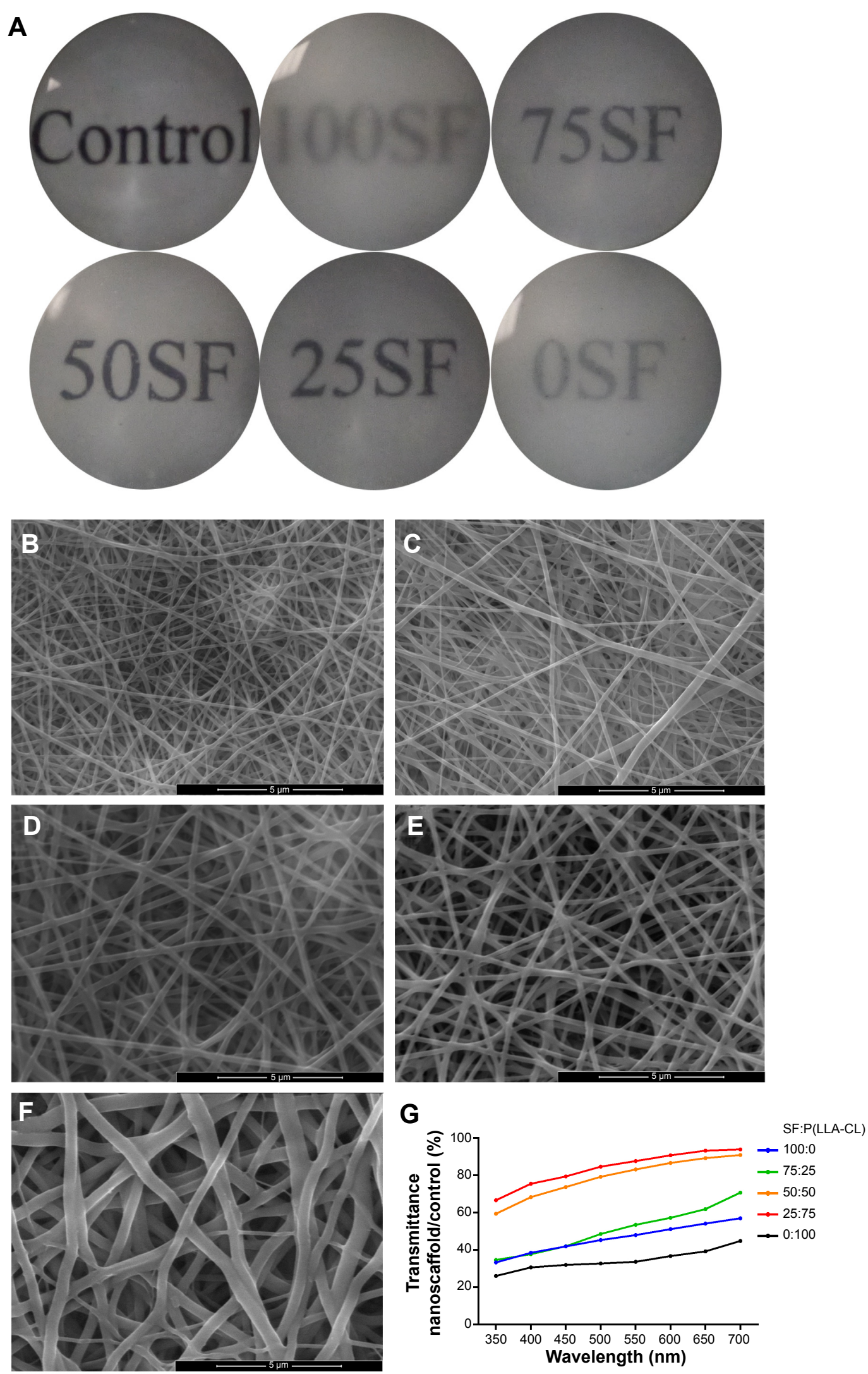

Figure I Transmission of light in nanofibrous membranes with different blend ratios.

Notes: General transmission of light is shown in (A). Scanning electron microscopy results are shown in (B-F). (B) $100 \%$ SF, (C) $75 \%$ SF, (D) $50 \%$ SF, (E) $25 \%$ SF, and (F) $0 \% \mathrm{SF}$. Scale bar, $5 \mu \mathrm{m}$. Accurate transmission percentage compared with the control group is shown in (G).

Abbreviation: $\mathrm{P}(\mathrm{LLA}-\mathrm{CL})$, poly(L-lactic acid-co- $\varepsilon$-caprolactone); SF, silk fibroin. 

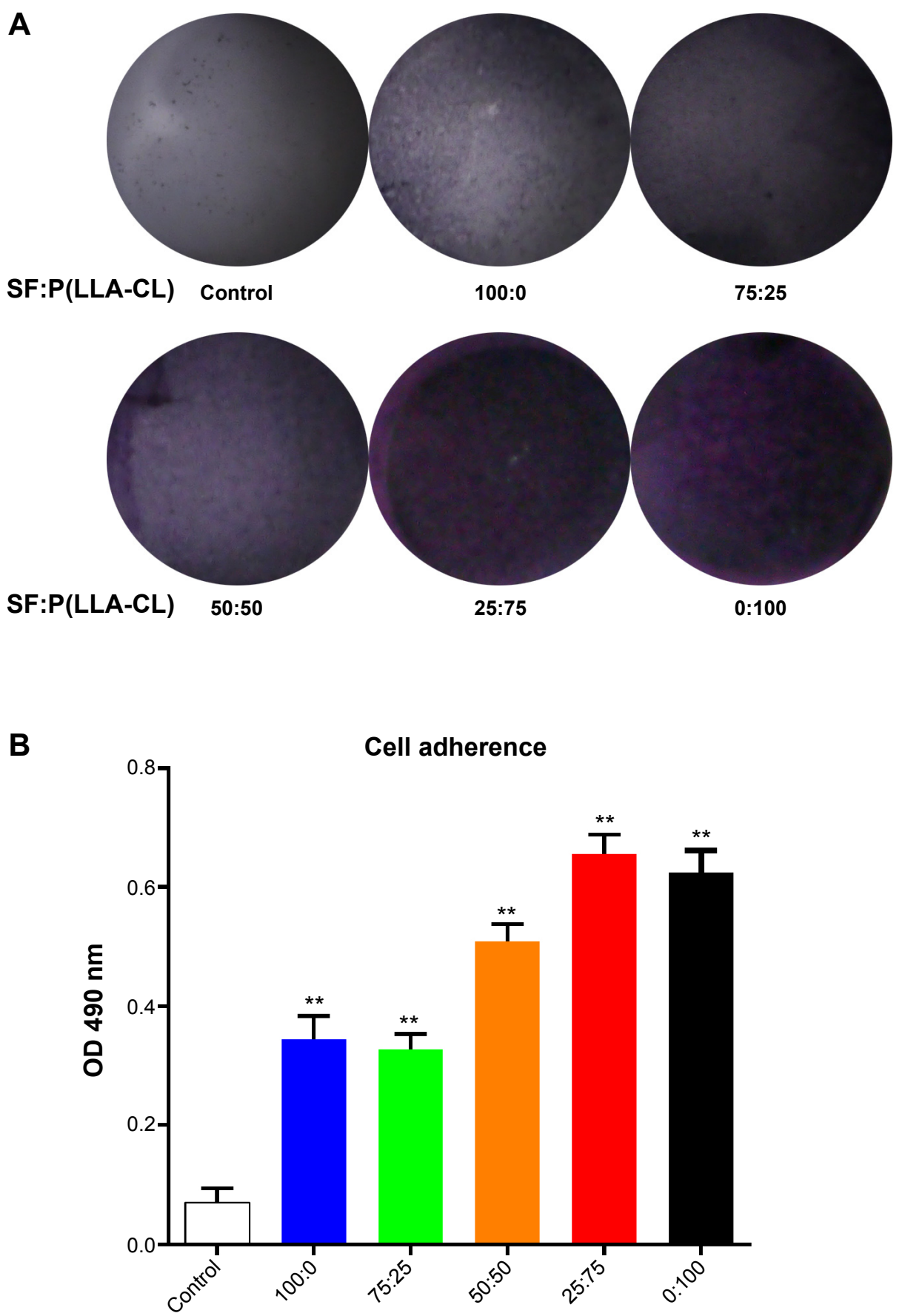

Figure 2 Cells adhering to different blend ratio nanoscaffolds.

Notes: Violet crystals reflect the HCEC-B4GI2 numbers and are recorded in (A). After dissolving the violet crystals in dimethyl sulfoxide, absorbance at 490 nm was measured, and the results are shown in $(\mathbf{B})$. ${ }^{*} P<0.01$.

Abbreviations: SF, silk fibroin; P(LLA-CL), poly(L-lactic acid-co-e-caprolactone); OD, optical density; HCEC, human corneal endothelial cells.

that the mRNA expression levels of collagen IV decreased in cells grown on pure SF and 75:25 SF:P(LLA-CL) scaffolds. The expression levels of collagen VIII decreased in cells grown on the 75:25 SF:P(LLA-CL) scaffold. These two types of collagen showed no significant difference in mRNA expression in cells grown on membranes with the other blend ratios when compared with the control. Levels of interleukin-1, an inflammation-related cytokine, and caspase 3, an apoptosis-related gene, were detected, as shown in Figure 5C. No significant differences were found.

\section{Discussion}

SF/P(LLA-CL) blended nanofibers demonstrated favorable mechanical properties and binding sites for cell attachment 


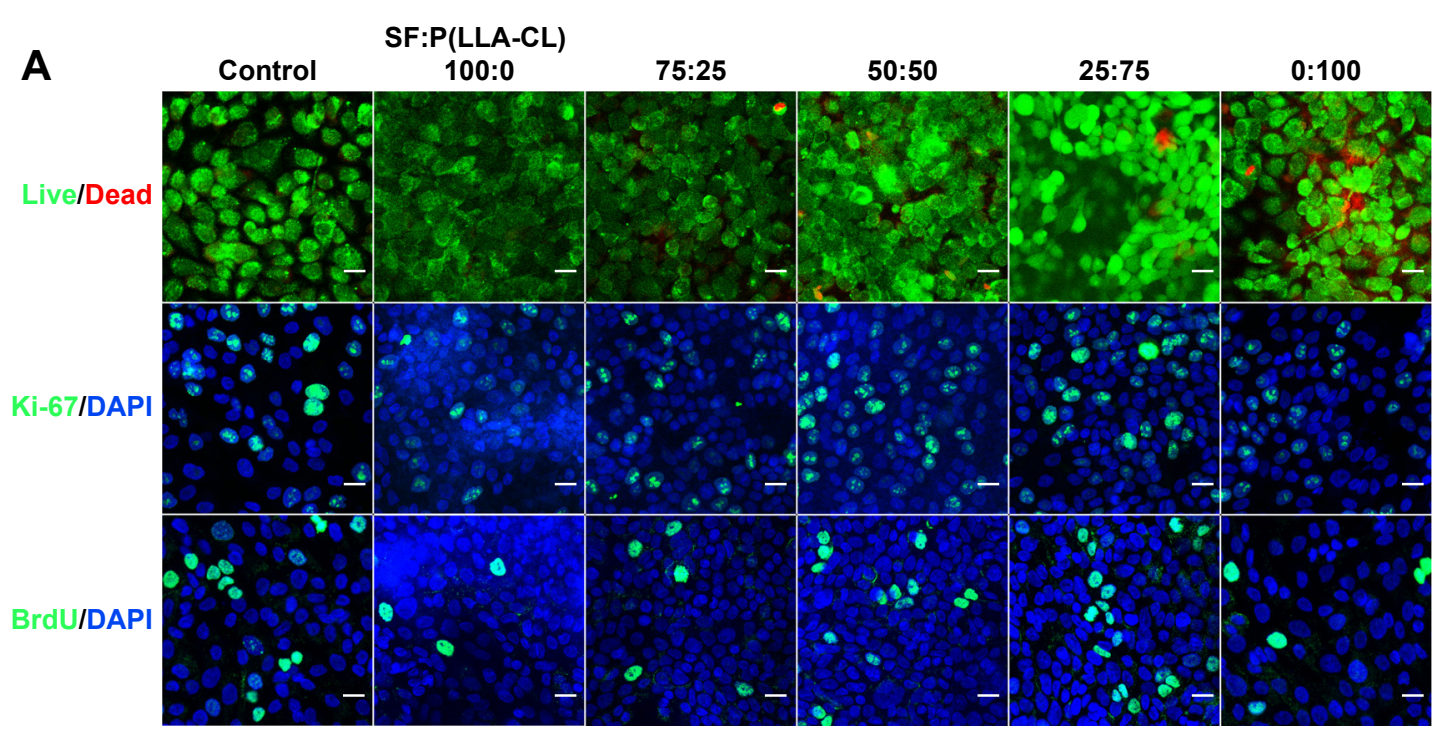

B

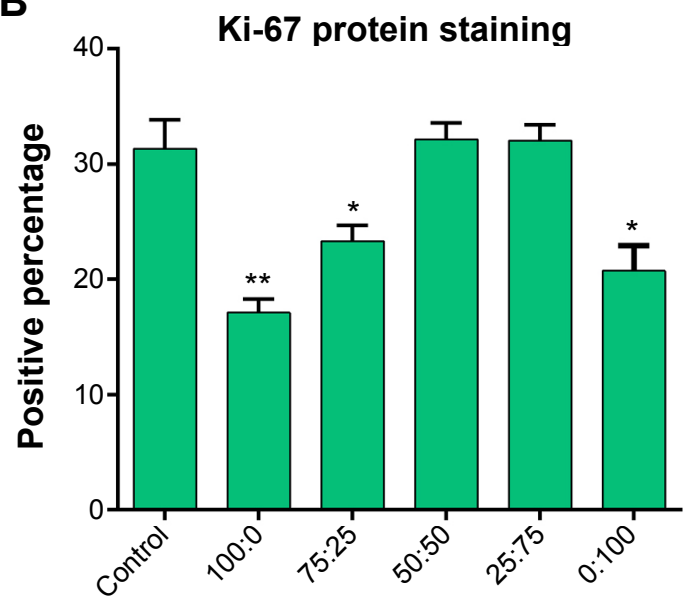

C

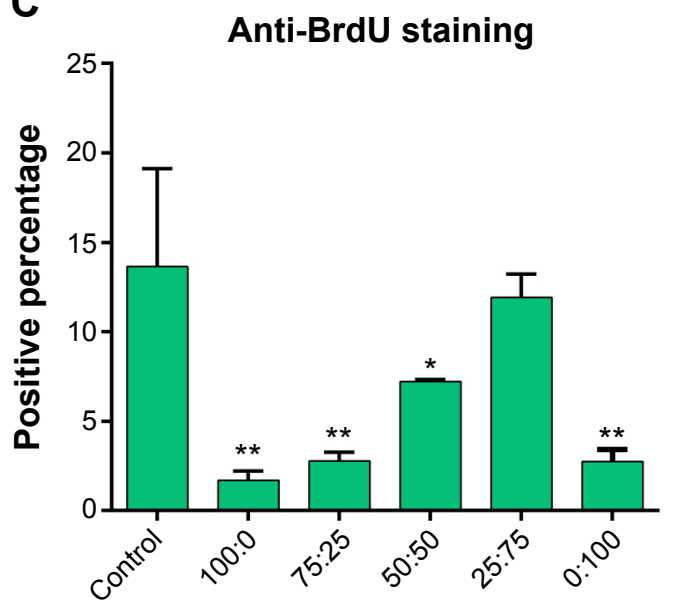

Figure 3 Cell viability and proliferation on different SF/P(LLA-CL) membranes.

Notes: The first row of $(\mathbf{A})$ shows the results of the live/dead kit test, and few dead cells can be seen. The second row of $(\mathbf{A})$ shows Ki-67 protein staining, and the third row of $(\mathbf{A})$ shows BrdU staining under laser scanning confocal microscopy. The scale bar indicates $50 \mu \mathrm{m}$ in $(\mathbf{A})$. The histogram of the positive percentage of Ki-67 protein staining is shown in (B). The histogram of the positive percentage of $\operatorname{BrdU}$ staining is shown in (C). $* P<0.05$, $* * P<0.01$.

Abbreviations: DAPI, 4,6-diamidino-2-phenylindole; SF, silk fibroin; P(LLA-CL), poly(L-lactic acid-co- $\varepsilon$-caprolactone).

and proliferation, indicating their potential application in vascular tissue engineering and nerve regeneration. ${ }^{27,28}$ Polymer nanofibers seem to be good materials for endothelial cells. ${ }^{29-31}$ Some studies of the use of SF or P(LLA-CL) in cornea tissue engineering have been reported, ${ }^{32-34}$ but none about the use of blended SF/P(LLA-CL) nanofiber membranes in regeneration of the corneal endothelium. The aim of our present study is to evaluate the feasibility of using nanofiber scaffolds for regeneration of the corneal endothelium. The cornea at the front of eye is a transparent window in humans, and must allow free passage of light and allow primary focusing without aberration. Substitutes for any of its layers need to be transparent and biocompatible with cells in the cornea layers and to have the necessary mechanical and functional attributes to perform their role. ${ }^{35,36}$ Basic features of the materials are shown in Table 2. In this study, we performed all of the above-mentioned tests to understand the advantages and disadvantages of using electrospun substitute materials in cornea tissue engineering. We compared nanoscaffolds containing different blend ratios and tried to determine the best blend ratio to use for regeneration of the corneal endothelium. Subsequent studies are needed to improve the material of this best ratio.

The transmission test showed that 25:75 was the most transparent blend ratio for SF and P(LLA-CL), and can reach 
A

Monolayer of HCEC-B4G12 on different scaffolds

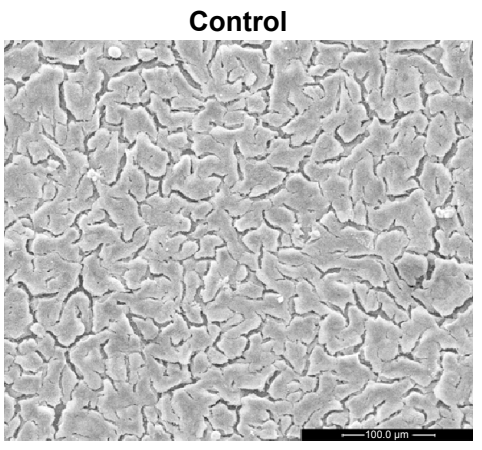

$50: 50$

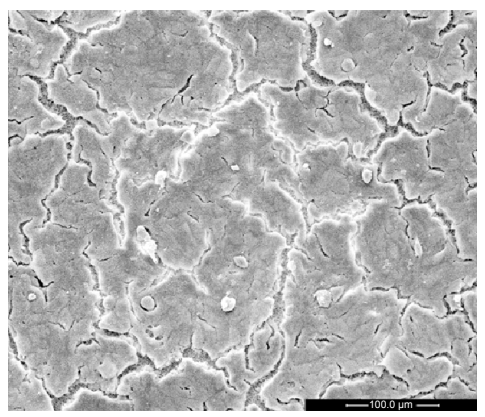

100:0

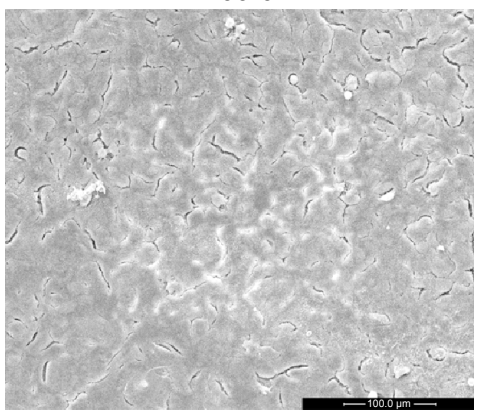

$25: 75$

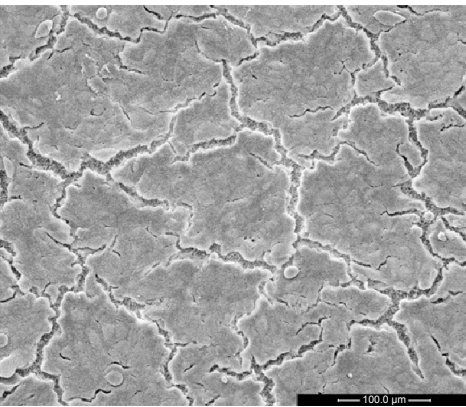

$75: 25$

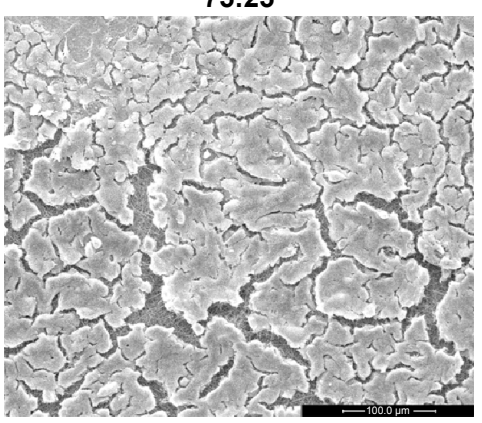

0:100

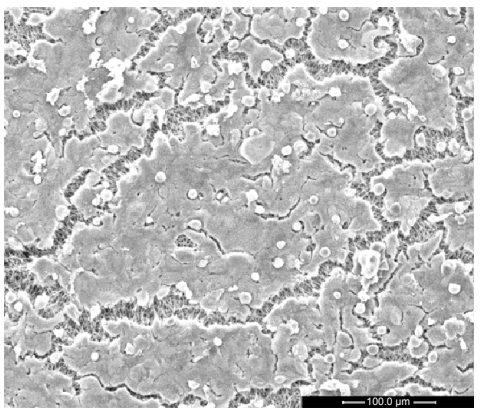

B

ZO-1/DAPI staining of monolayer

Control

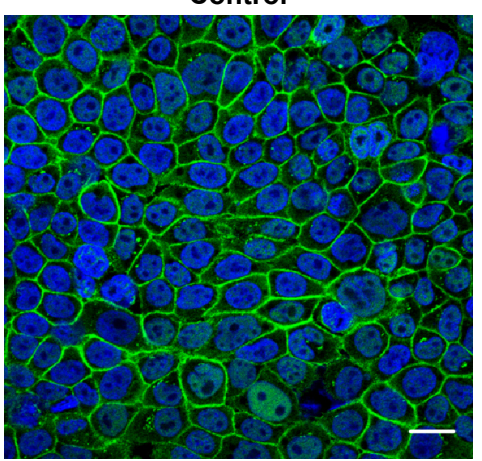

$50: 50$

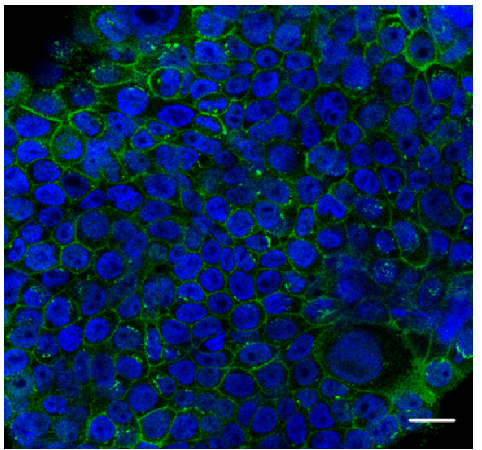

100:0

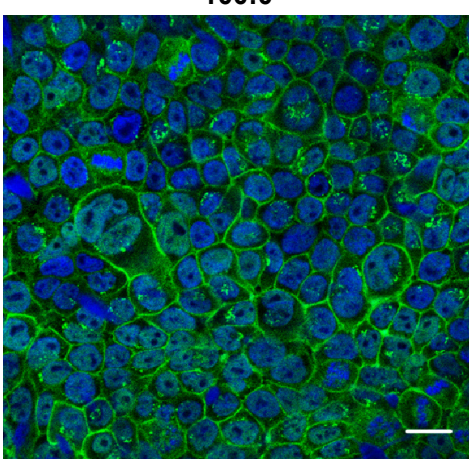

$25: 75$

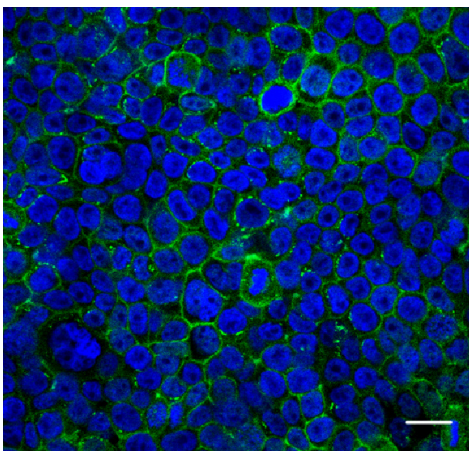

$75: 25$

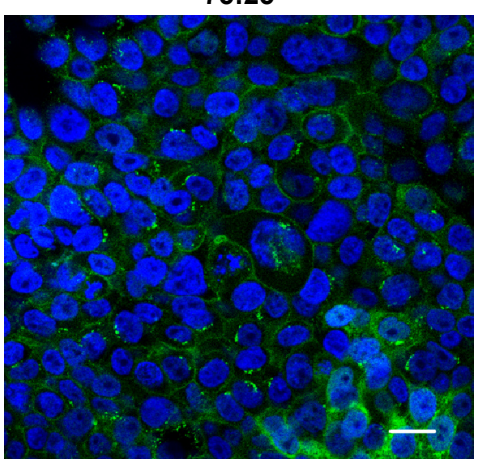

$0: 100$

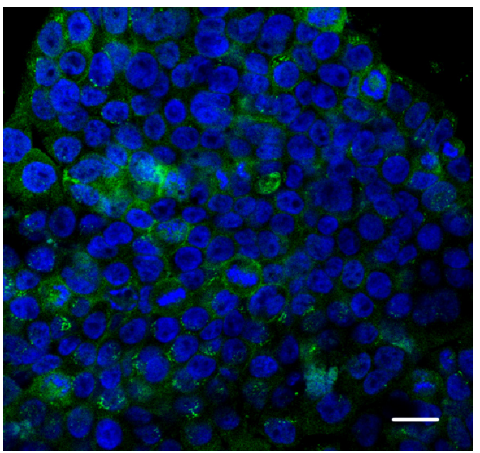

Figure 4 Monolayer formation on different SF/P(LLA-CL) membranes. HCEC-B4GI2 cells were cultured on different membranes for I week for monolayer formation. Notes: Scanning electron microscopic images showed that the B4GI 2 cells could form a monolayer on all membranes and on glass coverslips (control group), as shown in (A). ZO-I staining of monolayers is shown in (B). Scale bar, $20 \mu \mathrm{m}$.

Abbreviations: DAPI, 4,6-diamidino-2-phenylindole; SF, silk fibroin; P(LLA-CL), poly(L-lactic acid-co-ع-caprolactone); HCEC, human corneal endothelial cells; ZO-I, zona occludens-1. 


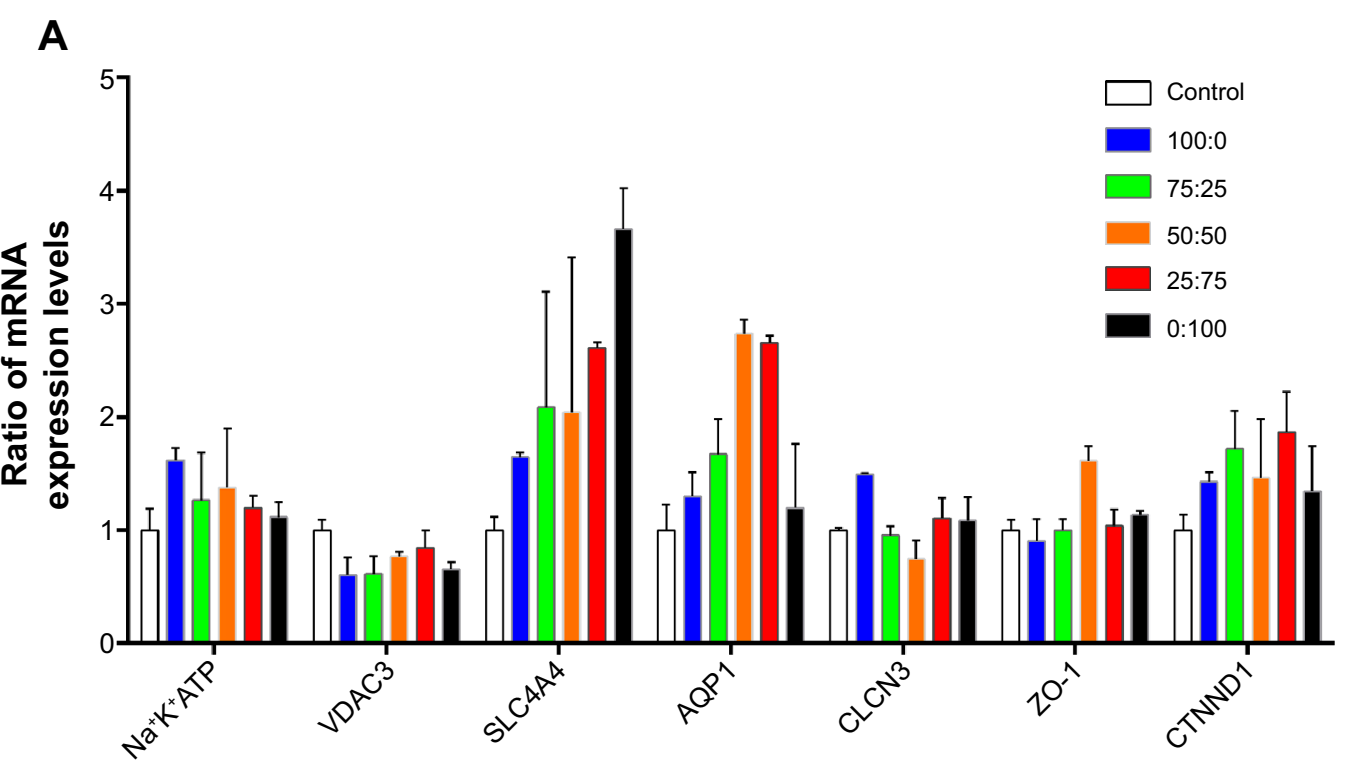

Endothelial functional genes

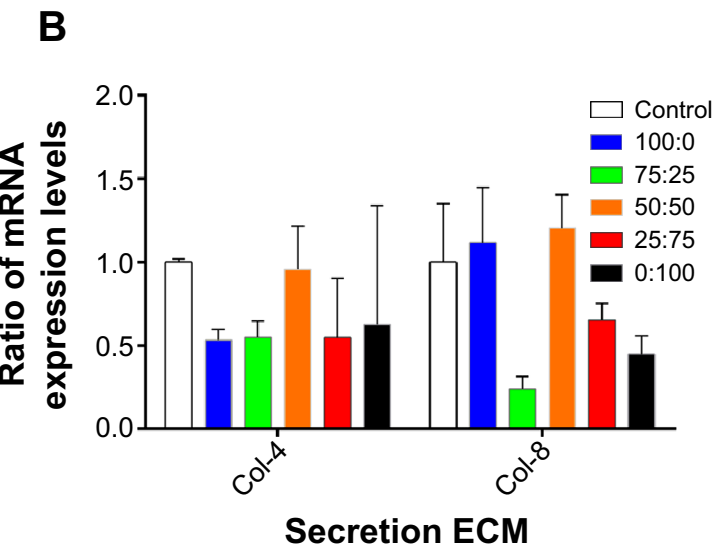

Secretion ECM

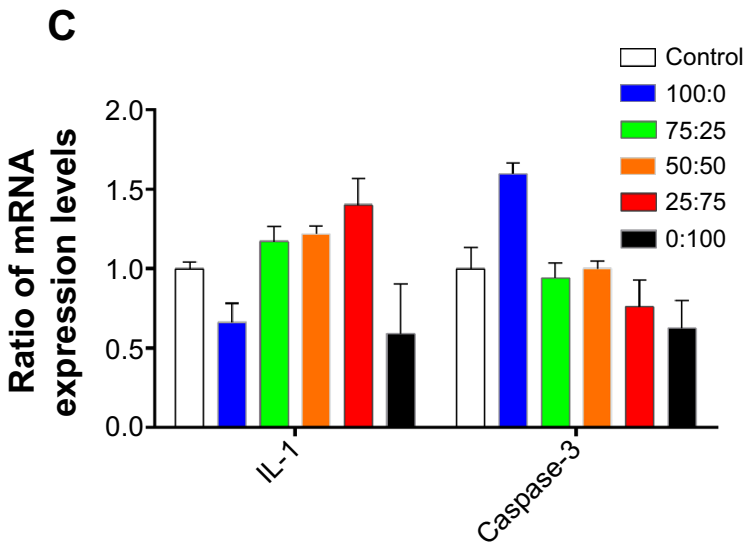

Inflammation and apoptosis

Figure 5 Gene expression on different membranes.

Notes: (A) Expression of seven functional correlation genes was tested. (B) Two extracellular matrices, collagen IV and collagen VIII, were detected. (C) Interleukin-I (an inflammatory cytokine) and caspase-3 (an apoptosis-related gene) were tested.

Abbreviations: AQPI, aquaporin I; CLCN3, voltage-sensitive 3 chloride channel; ZO-I, zona occludens-I; Col-4, collagen type IV; Col-8, collagen type VIII; CTNNDI, cadherin-associated protein; IL-I, interleukin-I; $\mathrm{Na}^{+} \mathrm{K}^{+}$ATPase, $\mathrm{Na}^{+} / \mathrm{K}^{+}$transporting, alpha I polypeptide; SLC4A4, sodium bicarbonate cotransporter member 4; VDAC3, voltage-dependent anion channel 3; ECM, extracellular matrix.

approximately $90 \%$ of the transparency of a glass coverslip. However, its transmission is slightly less than that of the SF film reported by Madden et al. ${ }^{14}$ Light scattering of the nanofibers is the most important factor influencing, and is unavoidable in electrospun materials. ${ }^{37}$ The diameter of the nanofibers and their hydrophilicity also had an effect on their ability to transmit light. All 8\% weight ratio electrospun materials are much thicker than the SF film mentioned above (the SF films were $5 \mu \mathrm{m}$ thick in the report). ${ }^{14}$ The tensile strength of the 25:75 membrane blend ratio was $9.39 \pm 0.69 \mathrm{MPa}$, which is far greater than that of the human Descemet's membrane (which has a wet measured tensile strength of $0.14 \mathrm{MPa}) .{ }^{38} \mathrm{~A}$ thinner electrospun nanoscaffold may provide better light transmission.

The electrospun nanoscaffolds showed a marked increase in cell adhesion speed when compared with the tissue culture plate surface. The same results were reported for mesenchymal stem cells on collagen electrospun fibers. ${ }^{39-41}$ The hydrophilic angle increases as the P(LLA-CL) concentration increases. We believe that simulation of a threedimensional extracellular matrix (ECM) and an increase in the hydrophilic angle play a major role in cell adhesion. ${ }^{16}$ Charge attraction may also contribute to cell adhesion. ${ }^{42}$ The 25:75 SF to P(LLA-CL) blend ratio showed the most rapid 
cell adhesion (Figure 2B), but was not significantly different from the cell adhesion speed in the pure P(LLA-CL) group.

The live-dead kit showed that all the scaffold blend ratios tested were safe and nontoxic. These results are consistent with those reported by other researchers. ${ }^{43,44} \mathrm{~A}$ few dead cells can be seen with the 75:25, 50:50, 25:75, and 0:100 blend ratios in Figure 3A, and we believe that these are cells that have died a natural death on the three-dimensional ECM. Both Ki-67 protein and BrdU staining show that the 25:75 blend was the most suitable ratio for cell proliferation when compared with the control group (Figure 3B and C). The 50:50 blend was the second best ratio for Ki-67 protein. $\mathrm{Ki}-67$ protein positive staining reflected cell in cell cycle. And BrdU specifically reflected S phase (DNA synthesis) in cell cycle. When cells were cultured on electrospun scaffolds, the scaffolds acted as one part of extracellular matrix. Different blend ratios made different nanofiber diameters and different hydrophilic angles. The difference affected cell proliferation and cell cycle on the scaffolds.

Dehydration of corneal endothelial cells requires a complete barrier in the monolayer. ${ }^{10}$ SEM indicated good biocompatibility and formation of a monolayer. The cracks seen on some scaffolds, in Figure 4A, were caused by dehydration through a graded ethanol series and then freeze-dried in SEM sample processing. ZO-1 is necessary as a cell barrier. ${ }^{45}$ Immunocytochemistry staining for ZO-1 showed completely tight junctions in the monolayer of cells on all the materials tested (Figure 4B). No differences were found between the electrospun scaffolds groups and the control group. Thus, a three dimensional electrospun scaffold does not affect cell-cell tight junctions, but electrospun scaffolds may affect cell secretion of ECM. Collagen type VIII is secreted by normal corneal endothelial cells as the part of the composition of Descemet's membrane. Collagen type IV is expressed abundantly in the B4G12 cell line. ${ }^{24}$ The mRNA levels for these two types of collagen decreased slightly on some of the blend ratio scaffolds when compared with the control group, but not in a consistent manner.

Real-time PCR was used to detect mRNA levels for seven functional genes, ie, four genes involving cell ion channels or the cell pump $\left(\mathrm{Na}^{+} \mathrm{K}^{+}\right.$ATPase, SLC4A4, voltage-dependent anion channel 3, voltage-sensitive 3 chloride channel), the water channel (aquaporin-1), and tight junction proteins (cadherin-associated protein, ZO-1). These genes are required for the cell barrier and dehydration of the corneal endothelium, ${ }^{10,45}$ and were expressed stably on all scaffolds.
The mRNA level for SLC4A4 did show an increase, and we believe that this may have resulted from material degradation leading to a change in local $\mathrm{pH} .{ }^{46}$ Interleukin-1 and caspase- 3 mRNA levels remained the same as those in the control group, indicating that these membranes do not cause an inflammatory reaction or apoptosis. The real-time PCR results were consistent with those of the live-dead test. Magnesium alloy tissue engineering scaffolds seem to be a promising method for preventing changes in local $\mathrm{pH}$ as a result of degradation of nanofibers based on the principle of acid-based neutralization. ${ }^{47}$

\section{Conclusion}

Combined SF and P(LLA-CL) electrospun scaffolds have good biocompatibility and have been studied in multiple areas of tissue regeneration. Our study demonstrates for the first time successful growth of HCEC on combined SF and P(LLA-CL) electrospun scaffolds as a step in evaluating the membrane as a substrate for transplantation of tissue constructs in endothelial keratoplasty. All ratios of materials could form monolayers with a complete barrier structure. The 25:75 blend ratio of SF and P(LLA-CL) showed the best ability to transmit light. Excellent mechanical properties allow it to be electrospun thinner for improved transmission. Further, the 25:75 blend ratio showed the highest percentage of Ki-67 and BrdU staining. These results suggest that the 25:75 blend ratio of SF and P(LLA-CL) is a potential bioengineering material for corneal endothelial transplantation and warrants further study.

\section{Acknowledgments}

The authors are grateful for the assistance of Dr Mo from Donghua University, Shanghai, People's Republic of China. This research was supported by grants from the National Natural Science Foundation of China (81370992, 31271029), the National High Technology Research and Development ("863") Program of China (2012AA020507), the Young Foundation of Shanghai Municipal Commission of Health and Family Planning (20144Y0221), and the Young Physicians Training Fund of Shanghai Municipal Commission of Health and Family Planning.

\section{Disclosure}

The authors report no conflicts of interest in this work.

\section{References}

1. Terry MA, Ousley PJ. Deep lamellar endothelial keratoplasty in the first United States patients: early clinical results. Cornea. 2001;20(3): 239-243. 
2. Price MO, Price FW Jr. Descemet's stripping with endothelial keratoplasty: comparative outcomes with microkeratome-dissected and manually dissected donor tissue. Ophthalmology. 2006;113(11):1936-1942.

3. Melles GR. Posterior lamellar keratoplasty: DLEK to DSEK to DMEK. Cornea. 2006;25(8):879-881.

4. McCauley MB, Price MO, Fairchild KM, Price DA, Price FW Jr. Prospective study of visual outcomes and endothelial survival with Descemet membrane automated endothelial keratoplasty. Cornea. 2011;30(3):315-319.

5. Rosenbaum K, Rottler J, Steinbach R, Huber KK. [Reduced availability of potential cornea donors: reasons and suggestions]. Klin Monbl Augenheilkd. 2010;227(5):418-422.

6. Shimazaki J, Shinozaki N, Shimmura S, Holland EJ, Tsubota K. Efficacy and safety of international donor sharing: a single-center, case-controlled study on corneal transplantation. Transplantation. 2004;78(2):216-220.

7. Proulx S, Brunette I. Methods being developed for preparation, delivery and transplantation of a tissue-engineered corneal endothelium. Exp Eye Res. 2012;95(1):68-75.

8. Mimura T, Yamagami S, Yokoo S, et al. Sphere therapy for corneal endothelium deficiency in a rabbit model. Invest Ophthalmol Vis Sci. 2005;46(9):3128-3135.

9. Engelmann K, Bednarz J, Valtink M. Prospects for endothelial transplantation. Exp Eye Res. 2004;78(3):573-578.

10. Joyce NC. Proliferative capacity of the corneal endothelium. Prog Retin Eye Res. 2003;22(3):359-389.

11. Tan DT, Anshu A, Mehta JS. Paradigm shifts in corneal transplantation. Ann Acad Med Singapore. 2009;38(4):332-338.

12. Wencan W, Mao Y, Wentao Y, et al. Using basement membrane of human amniotic membrane as a cell carrier for cultivated cat corneal endothelial cell transplantation. Curr Eye Res. 2007;32(3):199-215.

13. Yoeruek E, Saygili O, Spitzer MS, Tatar O, Bartz-Schmidt KU, Szurman P. Human anterior lens capsule as carrier matrix for cultivated human corneal endothelial cells. Cornea. 2009;28(4):416-420.

14. Madden PW, Lai JN, George KA, Giovenco T, Harkin DG, Chirila TV Human corneal endothelial cell growth on a silk fibroin membrane. Biomaterials. 2011;32(17):4076-4084.

15. Bray LJ, George KA, Ainscough SL, Hutmacher DW, Chirila TV, Harkin DG. Human corneal epithelial equivalents constructed on Bombyx mori silk fibroin membranes. Biomaterials. 2011;32(22):5086-5091.

16. Harkin DG, George KA, Madden PW, Schwab IR, Hutmacher DW, Chirila TV. Silk fibroin in ocular tissue reconstruction. Biomaterials. 2011;32(10):2445-2458

17. Bashur CA, Dahlgren LA, Goldstein AS. Effect of fiber diameter and orientation on fibroblast morphology and proliferation on electrospun poly(D,L-lactic-co-glycolic acid) meshes. Biomaterials. 2006;27(33):5681-5688

18. Xu C, Inai R, Kotaki M, Ramakrishna S. Electrospun nanofiber fabrication as synthetic extracellular matrix and its potential for vascular tissue engineering. Tissue Eng. 2004;10(7-8):1160-1168.

19. Zhang K, Wang H, Huang C, Su Y, Mo X, Ikada Y. Fabrication of silk fibroin blended P(LLA-CL) nanofibrous scaffolds for tissue engineering. J Biomed Mater Res A. 2010;93(3):984-993.

20. Chen F, Li X, Mo X, He C, Wang H, Ikada Y. Electrospun chitosan$\mathrm{P}(\mathrm{LLA}-\mathrm{CL})$ nanofibers for biomimetic extracellular matrix. J Biomater Sci Polym Ed. 2008;19(5):677-691.

21. Kwon IK, Kidoaki S, Matsuda T. Electrospun nano- to microfiber fabrics made of biodegradable copolyesters: structural characteristics, mechanical properties and cell adhesion potential. Biomaterials. 2005;26(18):3929-3939.

22. Liu Z, Yu N, Holz FG, Yang F, Stanzel BV. Enhancement of retinal pigment epithelial culture characteristics and subretinal space tolerance of scaffolds with $200 \mathrm{~nm}$ fiber topography. Biomaterials. 2014;35(9):2837-2850.

23. Kim BS, Mooney DJ. Development of biocompatible synthetic extracellular matrices for tissue engineering. Trends Biotechnol. 1998;16(5):224-230
24. Valtink M, Gruschwitz R, Funk RH, Engelmann K. Two clonal cell lines of immortalized human corneal endothelial cells show either differentiated or precursor cell characteristics. Cells Tissues Organs. 2008;187(4):286-294.

25. Eidet JR, Utheim OA, Raeder S, et al. Effects of serum-free storage on morphology, phenotype, and viability of ex vivo cultured human conjunctival epithelium. Exp Eye Res. 2012;94(1):109-116.

26. Chen H, Fan X, Xia J, et al. Electrospun chitosan-graft-poly ( $\varepsilon$-caprolactone)/poly ( $\varepsilon$-caprolactone) nanofibrous scaffolds for retinal tissue engineering. Int $J$ Nanomedicine. 2011;6:453-461.

27. Yin A, Li J, Bowlin GL, et al. Fabrication of cell penetration enhanced poly (1-lactic acid-co- $\varepsilon$-caprolactone)/silk vascular scaffolds utilizing air-impedance electrospinning. Colloids Surf B Biointerfaces. 2014;120:47-54.

28. Wang CY, Zhang KH, Fan CY, Mo XM, Ruan HJ, Li FF. Aligned natural-synthetic polyblend nanofibers for peripheral nerve regeneration. Acta Biomater. 2011;7(2):634-643.

29. He W, Ma Z, Yong T, Teo WE, Ramakrishna S. Fabrication of collagencoated biodegradable polymer nanofiber mesh and its potential for endothelial cells growth. Biomaterials. 2005;26(36):7606-7615.

30. Mo XM, Xu CY, Kotaki M, Ramakrishna S. Electrospun P(LLA-CL) nanofiber: a biomimetic extracellular matrix for smooth muscle cell and endothelial cell proliferation. Biomaterials. 2004;25(10):1883-1890.

31. He W, Yong T, Ma ZW, Inai R, Teo WE, Ramakrishna S. Biodegradable polymer nanofiber mesh to maintain functions of endothelial cells. Tissue Eng. 2006;12(9):2457-2466.

32. Guan L, Tian P, Ge H, et al. Chitosan-functionalized silk fibroin 3D scaffold for keratocyte culture. J Mol Histol. 2013;44(5):609-618.

33. Liu J, Lawrence BD, Liu A, Schwab IR, Oliveira LA, Rosenblatt MI. Silk fibroin as a biomaterial substrate for corneal epithelial cell sheet generation. Invest Ophthalmol Vis Sci. 2012;53(7):4130-4138.

34. Liu YC, Peng Y, Lwin NC, Venkatraman SS, Wong TT, Mehta JS. A biodegradable, sustained-released, prednisolone acetate microfilm drug delivery system effectively prolongs corneal allograft survival in the rat keratoplasty model. PLoS One. 2013;8(8):e70419.

35. Guan L, Ge H, Tang X, et al. Use of a silk fibroin-chitosan scaffold to construct a tissue-engineered corneal stroma. Cells Tissues Organs. 2013;198(3):190-197.

36. Bray LJ, George KA, Suzuki S, Chirila TV, Harkin DG. Fabrication of a corneal-limbal tissue substitute using silk fibroin. Methods Mol Biol. 2013;1014:165-178.

37. Chen F, Su Y, Mo X, He C, Wang H, Ikada Y. Biocompatibility, alignment degree and mechanical properties of an electrospun chitosan-P(LLA-CL) fibrous scaffold. J Biomater Sci Polym Ed. 2009; 20(14):2117-2128.

38. Danielsen CC. Tensile mechanical and creep properties of Descemet's membrane and lens capsule. Exp Eye Res. 2004;79(3):343-350.

39. Chan CK, Liao S, Li B, et al. Early adhesive behavior of bone-marrowderived mesenchymal stem cells on collagen electrospun fibers. Biomed Mater. 2009;4(3):035006.

40. Tian F, Hosseinkhani H, Hosseinkhani M, et al. Quantitative analysis of cell adhesion on aligned micro- and nanofibers. J Biomed Mater Res A. 2008;84(2):291-299.

41. Woo KM, Chen VJ, Ma PX. Nano-fibrous scaffolding architecture selectively enhances protein adsorption contributing to cell attachment. J Biomed Mater Res A. 2003;67(2):531-537.

42. Hu X, Tang-Schomer MD, Huang W, Xia XX, Weiss AS, Kaplan DL. Charge-tunable silk-tropoelastin protein alloys that control neuron cell responses. Adv Funct Mater. 2013;23(31):3875-3884.

43. Tsuji H, Tezuka Y. Alkaline and enzymatic degradation of L-lactide copolymers, 1. Amorphous-made films of L-lactide copolymers with D-lactide, glycolide, and epsilon-caprolactone. Macromol Biosci. 2005;5(2):135-148.

44. Dong Y, Yong T, Liao S, Chan CK, Ramakrishna S. Long-term viability of coronary artery smooth muscle cells on poly(L-lactide-co-epsiloncaprolactone) nanofibrous scaffold indicates its potential for blood vessel tissue engineering. $J R$ Soc Interface. 2008;5(26):1109-1118. 
45. Zhu YT, Hayashida Y, Kheirkhah A, He H, Chen SY, Tseng SC. Characterization and comparison of intercellular adherent junctions expressed by human corneal endothelial cells in vivo and in vitro. Invest Ophthalmol Vis Sci. 2008;49(9):3879-3886.

46. Zhang K, Yin A, Huang C, et al. Degradation of electrospun SF/P(LLA-CL) blended nanofibrous scaffolds in vitro. Polym Degrad Stab. 2011;96:2266-2275.
47. Li H, Wu T, Zheng Y, El-Hamshary H, Al-Deyab SS, Mo X. Fabrication and characterization of $\mathrm{Mg} / \mathrm{P}$ (LLA-CL)-blended nanofiber scaffold. J Biomater Sci Polym Ed. 2014;25(10):1013-1027.

International Journal of Nanomedicine

Dovepress

\section{Publish your work in this journal}

The International Journal of Nanomedicine is an international, peerreviewed journal focusing on the application of nanotechnology in diagnostics, therapeutics, and drug delivery systems throughout the biomedical field. This journal is indexed on PubMed Central, MedLine, CAS, SciSearch ${ }^{\circledR}$, Current Contents ${ }^{\circledR} /$ Clinical Medicine, Elsevier Bibliographic databases. The manuscript management system is completely online and includes a very quick and fair peer-review system, which is all easy to use. Visit http://www.dovepress.com/ testimonials.php to read real quotes from published authors.

Submit your manuscript here: http://www.dovepress.com/international-journal-of-nanomedicine-journal 